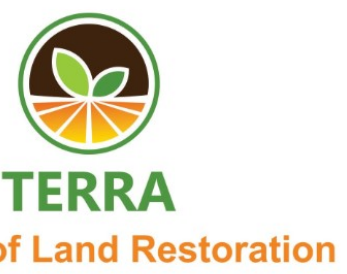

\title{
Effect of Biourine on N Uptake and Cabbage (Brassica oleraceae L) Growth on Lowland Ultisol
}

\author{
Amin Nur Rohman ${ }^{1}$, M. Faiz Barchia ${ }^{1 *}$, Bambang Gonggo Murcitro ${ }^{1}$ \\ ${ }^{1}$ Soil Science Department, University of Bengkulu (Corresponding author) \\ e-mail:@unib.ac.id
}

\begin{abstract}
Research on the effect of doses of cattle biourine on plant $N$ levels and growth of cabbage (Brassica oleraceae, L) in lowland Ultisol was carried out by Desa Bakti in Marga Sakti Sebelat District, North Bengkulu Regency in October 2019 to January 2020. This study aimed to determine the dosage of cattle biourine optimal for N levels and cabbage growth in lowland ultisols. This study used a Randomized Complete Block Design (RCBD) of one factor consisting

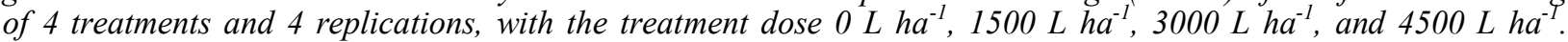
Observation data were analyzed by Analysis of variance (ANOVA) at a level of 5\% with the Orthogonal Polynomial Test. The results of the study showed that the optimum dosage was not obtained on the variable N levels of plants and soil $\mathrm{pH}$, but had a very significant effect on both of these variables. The optimum dosage obtained on the variable growth and yield of plants includes the optimum dose of $2250 \mathrm{~L} \mathrm{ha}$-1 biourine producing an average plant height of $36.14 \mathrm{~cm}$ age 45 dap, the optimum dose of $2200 \mathrm{~L} \mathrm{ha}$ of biourine produces an average plant height of $37.87 \mathrm{~cm}$ age 60 dap, optimum dose of biourine $1250 \mathrm{~L} \mathrm{ha}{ }^{-1}$ produces an average biomass fresh weigh $1.33 \mathrm{~kg}$, the optimum dose of biourine $1666.67 \mathrm{~L} \mathrm{ha}^{-1}$ produces an average head weight of $0.83 \mathrm{~kg}$, and optimum dose of biourine $2000 \mathrm{~L} \mathrm{ha} \mathrm{h}^{-1}$ produces average head diameter of $15.36 \mathrm{~cm}$.
\end{abstract}

Keywords: cow biourine, Ultisol, cabbage, plant $N$ content

\section{INTRODUCTION}

Ultisol is a type of soil spread in Indonesia, with a spread of $45,794,000$ ha or equal to $25 \%$ of the land area of Indonesia (Subagyo et al., 2004). Ultisol generally has a base saturation of $<35 \%$, sour reaction to very sour ( $\mathrm{pH} 5-3.1)$, good drainage, fine to medium texture, low soil nutrient content, and Clay CEC $<12$ me/100 g clay. (Hermawan et al., 2014). The Ultisol has a cross-section of land in flat to the mountain, slope $1-40 \%$, with an area of 706,000 ha which is the second widest type of land after Inceptisol in the province of Bengkulu.

The quality of soil fertility can be improved by adding organic ingredients. Organic matter can improve the nature of Ultisol and also able to improve crop yield. The addition of organic materials on the soil has a very important function in fertilizing the surface layer (topsoil), increase the population of microorganisms in the soil, increase water absorption by the soil and overall improve the quality of soil fertility and there are important supporting factors in organic farming is organic fertilizer, organic fertilization can mobilize existing nutrients in the soil so easily absorbed by plant roots. (Mulyani, 2010).

Solid organic fertilizer is now more utilized in farming, while in the form of liquid, especially urine still not much utilized (Adijaya et al., 2010). Judging from the nutrient aspect, the cow's urine fluid has a higher nutrient content compared to the density of impurities (Lingga, 1999). Cow urine can be utilized as a liquid organic fertilizer through the fermentation process by involving the role of microorganisms, so it can be a more beneficial agricultural product commonly referred to as Biourine (Sutari, 2010).

Biourine is a liquid organic fertilizer derived from the fermentation of anaerobic cow urine with additional nutrients using microorganisms (Wati et al., 2014). The result of fermentation in addition to reducing the pungent odor is also better quality than fresh cow urine, nutrient levels in the cow urine before fermentation contains $\mathrm{N}(1.0 \%), \mathrm{P}(0.5 \%) \mathrm{K}$ $(1.4 \%)$ and $\mathrm{Ca}(1.1 \%)$ And after being fermented into a cow biourine include element $\mathrm{N}(2.7 \%)$, $\mathrm{P}$ (2.4\%) K (3.8\%) and $\mathrm{Ca}$ (5.8\%) (Affandi, 2008). While the solid cow manure contains elements $\mathrm{N}$ (0.3), $\mathrm{P}(0.2 \%), \mathrm{K}(0.15 \%)$, as well as $\mathrm{Ca}(0.2 \%)$ 
(Lingga, 1999). Liquid Organic fertilizer has several advantages namely contain certain substances such as microorganisms that are rare in solid organic fertilizer. Biourine can provide an increase in crop yield almost equivalent to plant-buried materials (Perdana, 2015).

Biourine is an alternative to increase the availability and efficiency of nutrient absorption for plants (Sofiana \& Syaban, 2017). The cow biourine gives a noticeable effect on the N-total, the rising value of N-total land followed by a dose amount of cow biourine fertilizer added. 98\% increase in N-total soil caused by an increase in the biourine dose of cows. The administration of cow Biourine gives a noticeable effect on the $\mathrm{N}$ plant concentration and absorption of $\mathrm{N}$ crops with followed by increasing the number of doses of cow biourine fertilizers added. Increased concentrations of $\mathrm{N}$ plants $80 \%$ caused by increasing the dose of cow's biourine fertilizer (Sari et al., 2019). Fertilizer efficiency response $\mathrm{N}$ showed the treatment of fertilizer efficiency $\mathrm{N}$ by $25 \%$ or $50 \%$ with the addition of organic materials capable of producing a greater number of leaves.

Cabbage (Brassica oleracea L) is a type of horticultural plant. Cabbage wants unflooded, loose, fertile, containing many organic ingredients and has a pH of about 5.5 to 6.5 . The high nutritional content is owned so that the plant is very potential to be cultivated. Production in cabbage plant cultivation can be increased with one of the efforts to provide nutrients for plants. Plant needs of the main nutrients $\mathrm{N}, \mathrm{P}, \mathrm{K}$ is quite high. The main nutrient is much needed in plants, especially in the vegetative phase. The plant needs higher $\mathrm{N}$ than other nutrients, but $\mathrm{N}$ is a limiting factor for crop productivity. N deficiency will cause plants not to grow optimally, while $\mathrm{N}$ excess in addition to inhibit plant growth will also cause pollution to the environment (Duan et al., 2007).

The $\mathrm{N}$ levels in the soil are generally classified as low, in certain conditions and situations $\mathrm{N}$ easy loss is transported through yields, drainage, and evaporation into the atmosphere. $\mathrm{N}$ is an inseparable part of the chlorophyll molecule and with the $\mathrm{N}$ administration in sufficient quantities will affect the vegetative growth of the optimal plant. Cabbage is one of the plant-producing leaves that require $\mathrm{N}$ whose role is very large in the metabolic process of plants. To overcome these problems can be done by the provision of organic materials, one of the potential organic materials at the moment is the cow Biourine. Thus research on the influence of cow biourine on absorption $\mathrm{N}$ plants and the growth of cabbage plants need to be done to answer these questions.

The purpose of this research is to determine the interaction of several biourine-dose cows against the uptake of $\mathrm{N}$-nutrient plants and the growth of cabbage in the lowland ultisol.

\section{MATERIAL AND METHOD}

The research took place from October 2019 to January 2020 in the village of Karya Bakti, Marga Sakti Sebelat District, North Bengkulu Regency. At a place height of $\pm 59 \mathrm{~m}$ from above sea level, with the Ultisol soil type.

The experimental unit is based on a Randomized Complete Block Design (RCBD) single factor consisting of 4 treatments and 4 repeats, with a dose treatment of $0 \mathrm{~L} \mathrm{ha}^{-1}, 500 \mathrm{~L} \mathrm{ha}^{-1}, 3000 \mathrm{~L} \mathrm{ha}^{-1}$, and $4500 \mathrm{~L} \mathrm{ha}^{-1}$. The implementation of research includes the manufacture of biourine, preparation of planting media, planting, fertilization, maintenance, sampling of soil and plants, as well as laboratory analysis.

The observation variables include the content of $\mathrm{N}$ plant using Kjeldahl method, soil $\mathrm{pH}$ using electrometry Method (Balai Penelitian Tanah, 2005), plant height $(\mathrm{cm})$, number of leaves (strands), head diameter $(\mathrm{cm})$, biomass fresh weight $(\mathrm{kg})$ and head weight $(\mathrm{kg})$ measured using a scale. The collected observation variable Data is analyzed by variant analysis (ANOVA) at a 5\% $\alpha$ level and the polynomials Orthogonal method to determine the relationship model between dependent and independent variables.

\section{RESULT AND DISCUSSION}

\section{$N$ Uptake}

The relationship between the cow biourine dose and the $\mathrm{N}$ uptake as seen in Figure 1. Increased $\mathrm{N}$ uptake aligned with increasing doses of biourine, each dose of $1 \mathrm{~L} \mathrm{ha}^{-1}$ will be followed by an increasing rate of $\mathrm{N}$ uptake of $0.00004 \%$. The contribution of biourine dose to the addition of the average $\mathrm{N}$ uptake rate is $79 \%$. These results are lower than the results of the research of Sari et al. (2019) which indicates that the concentration of $\mathrm{N}$ plant $95 \%$ caused by increasing the dose of biourine in peanut plants on Entisol.

The ground ability in providing $\mathrm{N}$ is strictly determined by the condition and amount of soil organic matter (Cookson et al., 2005). Plants absorb $\mathrm{N}$ in the form of ammonium and nitrate, these ions are derived from fertilization and decomposition of organic matter (Benbi et al., 2002)..

\section{Soil pH}

An increase in the amount of biourine given is always followed by an increase in soil $\mathrm{pH}$, with a coefficient $\mathrm{R}^{2}=73 \%$ (Figure 2 ). The provision of organic fertilizer can increase soil $\mathrm{pH}$, presumably because organic anions produced by organic acids through the decomposition process can neutralize $\mathrm{Al}$ (Idaryani \& Sahardi. 2016). In acid soils, organic fertilizers 
can increase soil $\mathrm{pH}$, because organic fertilizers can neutralize organic Al through the humic acid contained in every organic fertilizer that acts as a soil buffer (Hardjowigeno, 1995). These conditions can provide flexibility to change the reaction of the soil, while the $\mathrm{H}^{+}$ contained in the soil remains so that the measured soil $\mathrm{pH}$ increases. The research of Siburian et al. (2016) shows that the application of liquid organic fertilizer significantly influences soil acidity. Increasing the dose is always followed by an increase in soil $\mathrm{pH}$. The higher the dose of liquid organic fertilizer given, the $\mathrm{OH}$ - released by organic acids is higher than the lower dose of liquid organic fertilizer.

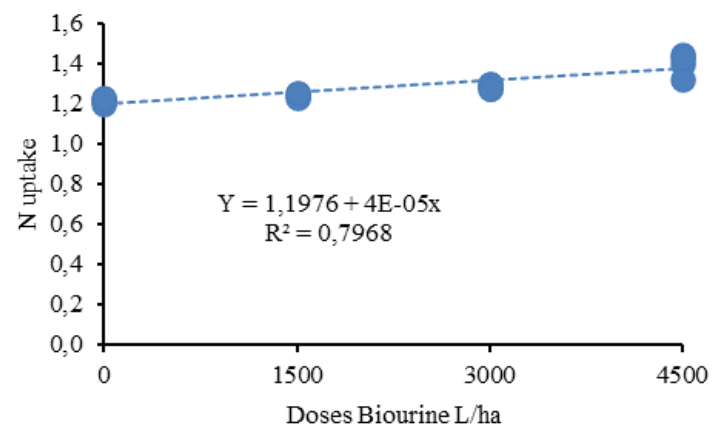

Fig 1. Correlation between biourine and $\mathrm{N}$ uptake

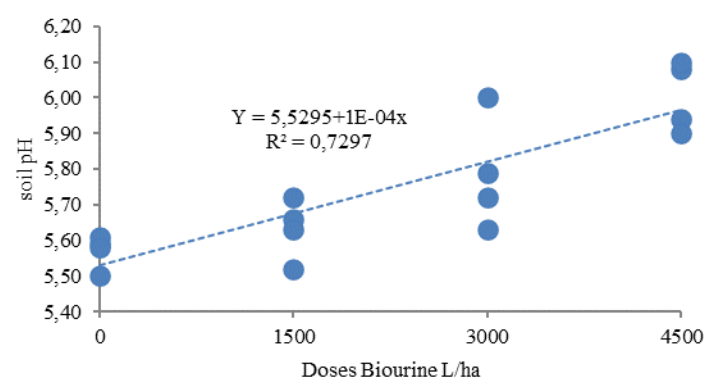

Fig 2. Correlation between biourine and soil $\mathrm{pH}$

\section{Plant Height}

The optimum dose of biourine of $2250 \mathrm{~L} \mathrm{ha}^{-1}$ yields an average plant height of $36.14 \mathrm{~cm}$ at 45 dap plant age. At the age of 60 days, the optimum dose of biourine was obtained at $2200 \mathrm{~L} \mathrm{ha}^{-1}$ which produced an average plant height of $37.87 \mathrm{~cm}$ (Figure 3). Yuliarta et al. (2014) showed that at plant age 42 and 56 daps there was a significant effect on the height of lettuce. Likewise the research results of Amanda et al. (2020) showed that biourine treatment had a significant effect on plant height. This is presumably because in this treatment the soil has the availability of organic fertilizer derived from cow urine so that it has a good impact on plant growth and development. Organic matter is a complete source of macro and micro essential nutrients, although in relatively small quantities
(Simanungkalit et al., 2006). In addition, organic fertilizer also contains many microorganisms, so that it can trigger the development of microorganisms that are already in the soil.

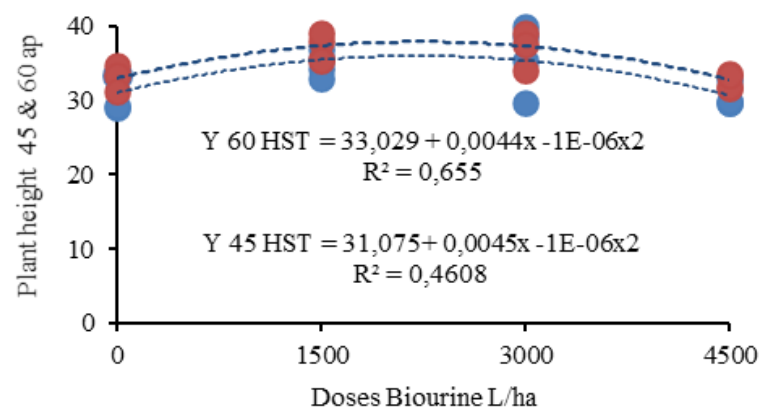

Fig 3. Correlation between biourine and plant height 45 and 60 after planting

\section{Biomass Fresh Weight}

The optimum dose of biourine is $1250 \mathrm{~L} \mathrm{ha}^{-1}$ which produces an average biomass fresh weight of $1.44 \mathrm{~kg}$ (Figure 4). Biourne has fast working properties and can stimulate plant development and increase crop production so that it gives a real influence on the fresh weight of plants (Amanda et al., 2020). The results of research by Nuraini et al. (2017) show that the application of biourine has a significant influence on the fresh weight of Pakchoi plants. The best treatment was able to increase the fresh weight of pakchoi plants to $26.06 \mathrm{~g}$ of plant $^{-1}$ or an increase of $405 \%$ compared without biourine. The results of the research Rizki et al. (2014) also showed that administering a dose of $400 \mathrm{~mL} \mathrm{~L}^{-1}$ fertilizer could increase the total fresh weight of green mustard plants by $380 \%$ compared without the administration of cow biourin. Increased fresh weight of plants can achieve optimal results because the plants get enough nutrients so that an increase in the number and size of cells can reach optimal levels and allow for an increase in plant water content (Arinong \& Lasiwua, 2011).

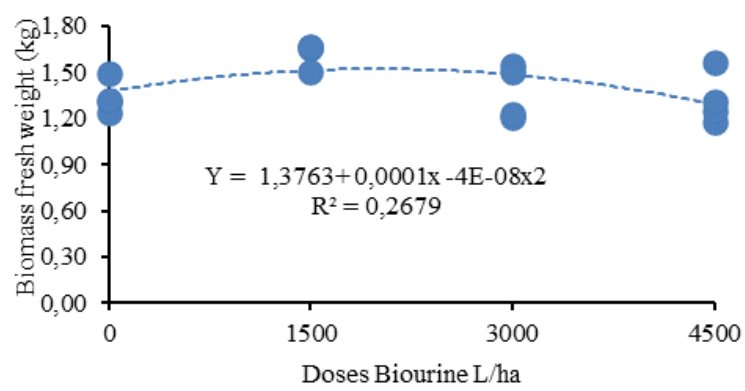

Fig 4. Correlation between biourine and bio mass fresh weight 


\section{Head Weight}

Based on the regression equation, the optimum dosage of biourine is $1666.67 \mathrm{~L}$ ha $^{1}{ }^{1}$, which results in an average head weight of $0.83 \mathrm{~kg}$ (Figure 5). These results are higher than the results of Yeshiwas research (2015) that obtained the highest crop weight of 0.771 $\mathrm{kg}$ plant- ${ }^{1}$ by giving fertilizer $\mathrm{N}$ of $150 \mathrm{~kg}$ ha- ${ }^{1}$. It is suspected that the efficiency factor of adding biourine can provide the nutrient requirements needed by cabbage. According to Subhan (1994), crop net weight is strongly influenced by the availability of nutrients in the soil and the balance of soil nutrients can affect yield. Also, according to Sulastri (2010), head weight is influenced by how much photosynthetic results are distributed to the crop area. This statement was also expressed by Wahyuni et al. (2004) that crop yield does not depend on how much photosynthate is given and produced but is also influenced by how much photosynthate is distributed to the plant parts.

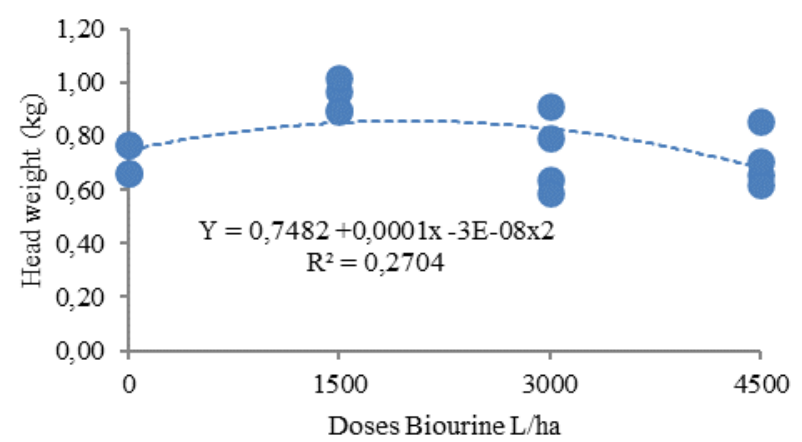

Fig 5. Correlation between biourine and head weight

\section{Head Diameter}

Increasing doses of biourine tend to increase the cabbage diameter of the cabbage plants with an optimum biourine dose of $2000 \mathrm{~L} \mathrm{ha}^{-1}$ which results in an average head diameter of $15.36 \mathrm{~cm}$ (Figure 6). This shows that the application of biourine at the optimum dose significantly affects the head diameter. The provision of liquid organic fertilizer is very instrumental in the growth of cabbage plants. Organic fertilizers contain macronutrients and micronutrients needed by plants for their growth which greatly affect the physical, chemical, and biological nature of the soil (Sutanto, 2002) as plant growing media. In excess doses tend to cause damage to the leaves as a result the leaves are inhibited in the formation of crop and so it can affect the amount of crop that is formed. Plants have certain limits on nutrient concentrations (Humadi et al., 2007).

Several variables have positive and negative relationships (Table 1). The results of the analysis indicated that the correlation between the growth variable and the plant yield includes the height of the plant, the biomass fresh weight, the head weight of the crop, and the positively correlated head diameter. This is suspected because the better the growth variables then also the better the crop results. Relationships between variables are expressed positively if the value of a variable is increased, it will increase the value of other variables (Zaynudin, 2010).

Analysis of the correlation between absorption $\mathrm{N}$ tissues with soil $\mathrm{pH}$ showed positive value, an increase in soil $\mathrm{pH}$ is closely related to element $\mathrm{N}$ so that increased soil $\mathrm{pH}$ also followed increased levels of $\mathrm{N}$ soil and plants. Soil packaging has a very important role because the soil solution contains essential elements that are useful for plants. If the $\mathrm{pH}$ of the soil solution is increased to above 5.5 then $\mathrm{N}$ becomes available to the plant in the form of nitrate (Patti et al., 2013).

According to Sunarjono (2011) that the most important condition to be fulfilled so that the cabbage grows well, namely the loose soil contains organic material, moist and low air temperature. Generally on lowland and high temperature cabbage plant is difficult to form crop, the other requirement is $\mathrm{pH}$ between 6-7 because cabbage is a plant very sensitive to low soil $\mathrm{pH}$. Following the results of the final soil analysis only gained increased soil $\mathrm{pH}$ from $5.6-6.0$, so on average has not reached the optimal growing requirement for cabbage plants.

Tabel 1. Correlation among experiment attributes

\begin{tabular}{|c|c|c|c|c|c|c|c|}
\hline & $\begin{array}{l}\text { Plant } \\
\text { Height } \\
45 \text { a.p. }\end{array}$ & $\begin{array}{l}\text { Plant } \\
\text { Height } \\
60 \text { a.p. }\end{array}$ & $\begin{array}{c}\mathrm{N} \\
\text { uptake } \\
(\%)\end{array}$ & $\begin{array}{c}\text { Biomass } \\
\text { Fresh } \\
\text { Weight } \\
\text { (kg) }\end{array}$ & $\begin{array}{c}\text { Head } \\
\text { Weight } \\
(\mathrm{kg})\end{array}$ & $\begin{array}{c}\text { Head } \\
\text { Diameter } \\
(\mathrm{cm})\end{array}$ & $\begin{array}{l}\text { Soil } \\
\mathrm{pH}\end{array}$ \\
\hline $\begin{array}{l}\text { Plant } \\
\text { Height } 45\end{array}$ & 1 & & & & & & \\
\hline $\begin{array}{l}\text { Plant } \\
\text { Height } 60\end{array}$ & 0,929852 & 1 & & & & & \\
\hline $\begin{array}{l}\text { N uptake } \\
(\%)\end{array}$ & $-0,23454$ & $-0,232$ & 1 & & & & \\
\hline $\begin{array}{l}\text { Biomass } \\
\text { Fresh }\end{array}$ & 0,210804 & 0,37717 & $-0,204$ & 1 & & & \\
\hline $\begin{array}{l}\text { Head } \\
\text { Weight } \\
\text { (kg) }\end{array}$ & 0,331764 & 0,44837 & $-0,197$ & 0,923805 & 1 & & \\
\hline $\begin{array}{l}\text { Head } \\
\text { Diameter } \\
(\mathrm{cm})\end{array}$ & 0,466929 & 0,60801 & $-0,286$ & 0,915336 & 0,93696 & 1 & \\
\hline Soil pH & $-0,02179$ & $-0,0565$ & 0,8091 & $-0,21726$ & $-0,2547$ & $-0,22861$ & 1 \\
\hline
\end{tabular}

\section{CONCLUSION}

The results of the study showed that the optimum dosage was not obtained on the variable $\mathrm{N}$ levels of plants and soil $\mathrm{pH}$, but had a very significant effect on both of these variables. The optimum dosage obtained on the variable growth and yield of plants includes the 
optimum dose of $2250 \mathrm{~L} \mathrm{ha}^{-1}$ biourine producing an average plant height of $36.14 \mathrm{~cm}$ age 45 dap, the optimum dose of $2200 \mathrm{~L} \mathrm{ha}^{-1}$ of biourine produces an average plant height of $37.87 \mathrm{~cm}$ age 60 dap, optimum dose of biourine $1250 \mathrm{~L} \mathrm{ha}^{-1}$ produces an average biomass fresh weight $1.33 \mathrm{~kg}$, the optimum dose of biourine $1666.67 \mathrm{~L} \mathrm{ha}^{-1}$ produces an average head weight of $0.83 \mathrm{~kg}$, and optimum dose of biourine $2000 \mathrm{~L} \mathrm{ha}^{-1}$ produces average head diameter of $15.36 \mathrm{~cm}$.

\section{References}

Adijaya, I. N. \& Kertawirawan, P. A. (2010). Respon jagung (Zea mays L.) terhadap pemupukan Bio Urin Sapi di lahan kering. . Balai Pengkajian Teknologi Pertanian Bali, Denpasar.

Affandi, 2008. Pemanfaatan Urine Sapi yang di fermentasi sebagai nutrisi tanaman. Andi Offset. Yogyakarta.

Amanda, M. F. \& Nugroho,A. (2020). Pengaruh aplikasi biourine sapi terhadap pertumbuhan dan hasil tanaman jagung manis (Zea mays saccharata L.). Jurnal Produksi Tanaman, 8(1), 41-48.

Arinong, A.R. \& Lasiwua, C.D. (2011). Aplikasi pupuk organik cair terhadap pertumbuhan dan produksi tanaman sawi. Jurnal Agrisistem, 7(1), 47-54.

Balai Penelitian Tanah. 2005. Petunjuk teknis analisis kimia tanah, pupuk, tanaman dan air. Balai Penelitian Tanah, Bogor.

Benbi, D.K. \& Richter, J.(2002). A critical review of some approaches to modelling nitrogen mineralization. Biol Fertil Soils.35, 168-183.

Cookson, W.R, Cornforth, I.S. \& Rowarth, J.S. (2002). Winter soil temperatur $\left(2-15^{\circ} \mathrm{C}\right)$ effect on nitrogen transformationsin clover green manure amandend and un amandend soils: a laboratory and field study. Soil Biol. Biochem., 34,1401-1415.

Duan, Y.H., Y.L. Zhang, L.Y. Ye, X.R Fan,GH Xu, G.H. \& Shen, Q.R. (2007). Responses ofrice cultivars with different nitrogen use efficiency to partial nitrate nutrition. Ann Bot., 99, 1153-1160.

Hardjowigeno, S. (1995). Ilmu Tanah. Akademika Pressindo. Jakarta.

Hermawan, A.,Sabarudin, Marsi, Hayati, R. \& Warsito. 2014. Perubahan jerapan P pada Ultisol akibat pemberian campuran abu terbang batubara kotoran ayam. Jurnal Ilmu Tanah dan Agroklimatologi, 11(1), 1-10.

Humadi, F. M. \& Abdulhadi, H.A. (2007).Effect of different sources and rates of nitrogen and phosphorus fertilizer on the yield and quality of Brassica juncea L. Journal Agricultur Resources, 7, $249-259$

Idaryani \& Sahardi. (2016). Respon beberapa sifat kimia dan hasil tanaman kakao terhadap pemberian pupuk organik dan pupuk hayati. Prosiding Seminar Nasional Inovasi Teknologi Pertanian
Banjarbaru, 20 Juli 2016, BPTP Sulawesi Selatan, Makasar.

Lingga, P. (1999). Petunjuk Penggunaan Pupuk. Penebar Swadaya, Jakarta.

Mulyani, A., Rachman, A. \& Dairah, A. (2010). Penyebaran Lahan Masam, Potensi dan Ketersediaannya Untuk Pengembangan Pertanian. Dalam Prosiding Simposium Nasional Pendayagunaan Tanah Masam. Pusat Penelitian dan Pengembangan Tanah dan Agroklimat, Bogor.

Nuraini,Y.\& Asgianingrum,R.E.(2017). Peningkatan Kualitas biourin sapi dengan penambahan pupuk hayati dan molase serta pengaruhnya terhadap pertumbuhan dan produktivitas pakchoy. J. Hort. Indonesia, 8(3), 183-191.

Patti, P.S., Kaya, E. \& Silahooy, C. (2013). Analisis status nitrogen tanah dalam kaitannya dengan serapan $\mathrm{N}$ oleh tanaman padi sawah di Desa Waimital, Kecamatan Kairatu, Kabupaten Seram Bagian Barat.Agrologia, 2(1), 51-58.

Perdana, S.N., Dwi, W.S. \& Santoso, M. (2015). Pengaruh aplikasi biourin dan pupuk terhadap pertumbuhan dan hasil tanaman bawang merah (Allium ascalonicum L.). J. Prod. Tan. 3(6), 457-463.

Rizki, K., Rasyad, A. \& Murniati. (2014). Pengaruh pemberian urin sapi yang difermentasi terhadap pertumbuhan dan produksi tanaman sawi hijau (Brassica rafa). Jurnal Pertanian, 1(2), 1-8.

Sari, I., Darman, S. \& Amelia, R. (2019). Pengaruh biourine sapi terhadap serapan nitrogen dan hasil tanaman kacang tanah (Arachis hypogaea L.) pada Entisols Sidera. e-J. Agrotekbis,7(1), 2027.

Siburian, S,I., Suntari, R. \& Prijono, S. (2016). Pengaruh aplikasi urea dan pupuk organik cair (urin sapi dan kompos sampah) terhadap serapan N serta produksi sawi pada Entisol. Jurnal Tanah dan Sumberdaya Lahan, 3(1),303-310.

Simanungkalit, R.D.M.,Suriadikarta, D.A.,Saraswati, R. , Setyorini, D.\& Hartatik, W.(2006). Pupuk Organik dan Pupuk Hayati .Balai Penelitian dan Pengembangan Lahan Pertanian, Bogor.

Sofiana, R. \& Syaban, R A. (2017). Aplikasi pupuk biourine terhadap hasil dan mutu benih dua varietas kacang tanah (Arachis hypogaea L.). Journal of Applied Agricultural Sciences. 1(1), 63-71.

Subagyo, H., Suharta, N. \& Siswanto, A.B. (2004). Tanah-tanah Pertanian di Indonesia. Pusat Penelitian Tanah dan Agroklimat, Bogor.

Subhan. (1994,) Pengaruh pupuk fosfat dan dolomit terhadap pertumbuhan dan hasil kubis dataran tinggi (Brassica oleraceae L.) kultivar Green Coronet. Bul. Panet. Hort., 26(2), 15-22. 
Sulastri, E. (2010), Penurunan intensitas akar gada dan peningkatan hasil kubis dengan penanaman Caisin sebagai tanaman perangkap patogen. Skripsi. Universitas Sebelas Maret, Surakarta.

Sunarjono, H. H. (2011), Bertanam 30 Jenis Sayur, Penebar Swadaya, Jakarta.

Sunu, P., \& Wartoyo. (2006). Dasar Hortikultura. UNS Press. Surakarta.

Sutanto, R. (2002). Pupuk dan Cara Pemupukan.Penerbit Rineka Cipta, Jakarta.

Sutari, N. W. S. (2010). Pengujian kualitas Bio urine hasil fermentasi dengan mikroba yang berasal dari bahan tanaman terhadap pertumbuhan dan hasil tanaman sawi hijau (Brassica juncea L.). Tesis. Program Studi Bioteknologi Pertanian, Program Pascasarjana, Fakultas Pertanian, Universitas Udayana, Denpasar.

Wahyuni, T. S., Setiamihardja, R., Hermiati, N. \& Hendroatmodjo, K.H. (2004), Variabilitas genetik, heritabilitas, dan hubungan antara hasil umbi dengan beberapa karakter kuantitatif dari 52 genotip ubi jalar di Kendal Payak, Malang.
Zuriat Jurnal Ilmiah Biologi.15(2), 99-107.

Wati, Y. T., E.E. Nurlaelih, E.E. \& Santosa, M. (2014). Pengaruh aplikasi biourine pada pertumbuhan dan hasil tanaman bawang merah (Allium ascalonicum L.) Jurnal Produksi Tanaman. 8 (2), 613-619.

Yeshiwas, Y. (2015). Effect of different rate of nitrogen fertilizer on the growth and yield of cabbage (Brassica oleraceae) at Debre Markos, North West Ethiopia. African Journal of Plant Science, 11 (7), 276-281.

Yuliarta, B., Santoso, M. \& Heddy, S .(2014). Pengaruh biourine sapi dan berbagai dosis pupuk NPK terhadap pertumbuhan dan hasil Selada Krop (Lactuca sativa L.). Jurnal ProduksiTanaman, 1(6), 1-9.

Zaynudin, A. (2010). Korelasi antar sifat-sifat buah pada tanaman Srikaya (Annonas quamosa L.) di daerah Sukolilo, Pati, Jawa Tengah. Skripsi. Universitas Sebelas Maret, Surakarta. 